DOI: $10.31866 / 2410-1311.36 .2020 .221066$

УДК 130.2:[159.937: 37.017]:82.0

\title{
- СПРИЙНЯТТЯ ТА ВИКЛАДАННЯ ХУДОЖНЬОЇ ТВОРЧОСТІ ЗА ТЕКСТАМИ ХАРКІВСЬКОГО КУЛЬТУРОЛОГА ОЛЕКСІЯ СЕЛІВАЧОВА
}

\section{- Гаврилюк Алла Степанівна}

- Аспірантка,

ORCID: 0000-0002-6833-6462, e-mail: alla_stepp@ukr.net,

Київський національний університет культури і мистецтв,

вул. Є. Коновальця, 36, Київ, Україна, 01133

\section{- Для цитування:}

Гаврилюк, А.С. (2020). Сприйняття та викладання художньої творчості за текстами харківського культуролога Олексія Селівачова. Питання культурології, (36), 195-205. doi: https://doi. org/10.31866/2410-1311.36.2020.221066.

\section{- Анотація}

Мета статті - конкретизувати світоглядні, естетичні й етичні чинники радикальної переоцінки значення класики для сучасності на початку XX століття, в період, який заведено називати «срібним віком» культури. Актуальність теми випливає з висвітлення одного з аспектів зміни гуманітарного дискурсу на етапі революційного переходу від однієї соціально-політичної формації до іншої. Методологія дослідження. Зазначена в меті статті проблема розглядається на основі аналізу науковопубліцистичної діяльності одного з талановитих молодих представників академічного харківського середовища, котрий писав дисертацію під опікою академіка М. Сумцова, досліджуючи проблеми сприйняття та викладання художньої творчості. Джерелами дослідження слугували в основному неопубліковані рукописи О. Селівачова, що зберігаються в родинному архіві. Наукова новизна полягає у введенні заначених джерел до наукового обігу. Висновки. Процеси такого переосмислення, де вищою точкою стало вульгарно-соціологічне приниження мистецької класики внаслідок подій 1917 року, розпочалися не в пролетарських гуртках, а в академічних колах, які згодом чи не найбільше постраждали від революції. Продемонстровано помітне прагнення О. Селівачова зрозуміти та пояснити протиріччя в творах і вчинках досліджуваних ним персонажів, оскільки суперечності, як чинники поступу, постійно привертали увагу науковця. Виявлено, що розглянуті тексти О. Селівачова яскраво відбивають ідейні суперечності революційної доби щодо ставлення до класики та новітніх форм художньої творчості в аспекті пріоритету естетичних або морально-дидактичних критеріїв. З'ясовано, що глорифрікація наприкінці XIX ст. фольклорної та поетичної класики швидко змінювалася на початку наступного століття критичним ставленням. I сприяли цьому найрізноманітніші чинники у широкому спектрі від консервативних 
антипрогресистських ідей - до модерністських і авангардних інтенцій радикального оновлення.

Ключові слова: художня творчість; поезія; сприйняття художнього твору; переоцінка цінностей; класика і сучасність; викладання; срібний вік

\section{- Вступ}

Філософські та психологічні основи художньої діяльності складають одну з наскрізних ліній у науковій творчості О. Селівачова, починаючи від його студентського дослідження «3 сучасної російської лірики» (Селивачёв,1911), виконаного під час навчання в мюнхенському та лейпцизькому університетах (1909-1911), й закінчуючи останніми датованими текстами 1919 року. За цей період ним написано на різні теми в різних жанрах понад 10 аркушів (збереглося близько 260 сторінок), які становлять репрезентативний матеріал і для висвітлення його позиції, й для фрормулювання наших висновків.

Відзначимо, що в дусі доби нашого автора найбільше ваблять символіка й містика. Тому й пише він здебільшого про фрілософрів і митців, яких умовно називають декадентами, містиками, символістами. Часто згадує К. Бальмонта, О. Блока, В. Брюсова, В. Іванова, Ф. Сологуба, М. Чурльоніса. І передусім на матеріалі їхньої творчості 1915 року підготовлена серія доповідей Олексія Федоровича на тему «Містицизм у поезії та живопису» (Селивачёв, 1915). Дослідник виділяє серед названих імен дві групи. Перша - це «поети життя» (К. Бальмонт, В. Брюсов, Ф. Сологуб), а друга - «поети мрії» (О. Блок, В. Іванов, М. Чурльоніс). Поезію перших, що не потребує тлумачень, Селівачов уподібнює квітам, які живляться реальним ґрунтом. А поезію других порівнює з квіткою, чиє коріння у воді. Вона живиться переважно не життєвими, а літературними враженнями, тому туманна, недостатньо зрозуміла для сприйняття без пояснень і коментарів.

Впродовж життя молодий вчений, зайнятий здебільшого викладанням у гімназіях Дуббельна (Латвія), Новочеркаська, Вільна, Харкова (серед його учнів Михайло та Микола Бахтіни, Олександр Квятковський), встиг оприлюднити лише кілька своїх статей і доповідей (Селивачёв, 1916a; 1917), які були оцінені такими відомими сучасниками, як М. Гершензон, П. Струве, М. Сумцов. Передчасна смерть на 33-му році життя та буремні події XX ст. зумовили повернення праць О. Селівачова до ширшого наукового вжитку лише 1995 року, коли почали передруковувати та публікувати невідомі раніше рукописи. Література про нього - чотири хоч і стислі, проте ґрунтовні розвідки доктора мистецтвознавства А. Пучкова та кандидата технічних наук Ю. Марченка, що побачили світ у київських, віленських і чебоксарських виданнях (Пучков, 2003; 2006; Puczkow \& Marczenko, 2013; Пучков \& Марченко, 2016). Згодом до них додалася й наша розвідка про родовід і нащадків Олексія Федоровича (Гаврилюк, 2020).

\section{- Мета статті}

Конкретизувати чинники радикальної переоцінки значення класики для сучасності на початку XX століття, спираючись на дослідження науково-публіцистичної діяльності О. Селівачова, його праці з питань сприйняття та викладан- 
ня художньої творчості. Зазначена проблема розглядається на основі аналізу науково-публіцистичної діяльності одного з талановитих молодих представників академічного харківського середовища, котрий писав дисертацію під опікою академіка М. Сумцова, досліджуючи проблеми сприйняття та викладання художньої творчості. Джерелами дослідження слугували в основному неопубліковані рукописи О. Селівачова, що зберігаються в родинному архіві.

\section{Виклад матеріалу дослідження}

Характер наукової діяльності О. Селівачова значною мірою зумовлений його професією викладача. Далекий у власних історико-теоретичних розвідках від дидактики та моралізаторства, він не міг не зважати на цей аспект, випробовуючи свої спостереження й умоглядні побудови гімназичною практикою та ділячись своїм досвідом з колегами по вчительській корпорації.

Знавець вітчизняної словесності О. Селівачов усвідомлює неможливість ії̈ охоплення гімназистами в повному обсязі, що забезпечує цілісне та повноцінне сприйняття, тому й обстоює поглиблене їх ознайомлення тільки за обраними вчителем зразками, замість хронологічного вивчення історії літератури, що вимушено стає пунктирно-фррагментарним за умов хронічного дефіциту навчальних годин і перевантаження учнів.

Понад те, він у багатьох текстах аргументує думку про важливість вивчення літератури передусім як засобу формування мовної компетенції учня, що дозволить йому навчатися самостійно мислити та виразно, правильно й адекватно висловлюватися. Ця ідея найретельніше розгорнута в його доповіді про методику роботи з написання гімназистами творів, яку він виголосив на харківському педагогічному з'їзді 7 червня 1916 року (Селивачёв, 1916с).

Хоча світоглядна позиція в текстах Олексія Федоровича прямо майже не виражена, в університетських дискусіях він дотримувався правих поглядів, опонував атеїзму та соціал-демократичній пропаганді. Принаймні, це випливає з адресованих до нього листів, яких збереглося близько двохсот. Але Селівачов адепт новітнього мистецтва. Переваги останнього для сучасного сприйняття, зосібна гімназистами, він аргументує системою доказів, які можна узагальнено звести до таких пунктів:

1) суголосність добі, психологічна близькість сучасникам;

2) високі художні властивості, зокрема, розмаїтість форм і виражальних засобів, актуальна тематика;

3) пріоритет естетичного над раціональним, що звільнює серцевину мистецтва - лірику - від невластивих їй завдань.

Ці тези О. Селівачов ілюструє, зокрема, прикладами рим, які в новітній поезії трапляються не тільки в кінці, а й усередині рядків; крім попередніх чоловічої, жіночої та дактилічної рими (де наголошується третій склад від кінця), входять у вжиток 4-х складова, наприклад: зака́нчивая - зама́нчивая (вже у Я. Полонського), засте́нчивая - уве́нчивая, і навіть п'ятискладова (ско́вывающий очаро́вывающий, протягиваются - притра́гиваются), комбінуються рядки різних розмірів, уперше з'являються семистопні рядки, чотирьохскладові стопи тощо (Селивачёв, 1911, с. 8-9). 
У цьому, так би мовити, «новому виданні суперечки старих і нових» інтонація його текстів інколи виявляє втому (не без епатажу) від властивої XIX століттю своєрідної «канонізації» класики, починаючи з усного фольклору, що багатьма вважався в ту добу ніби підвалинами народної самоідентифікації.

Найбільш концентровано критика ним усної простонародної творчості в аспекті її педагогічних можливостей щодо сприйняття учнями, розгорнута в неопублікованій статті про викладання мови та словесності в середній школі, закінченій у Харкові 17 вересня 1918 року (Селивачёв, 1918a), тобто, до утвердження там більшовицького режиму. Наче випереджаючи ймовірні закиди щодо її змісту, О. Селівачов оснащує статтю аж двома епіграфами («Censeo Carthaginem esse delendam» і «Поспішайте висловлювати парадокси, поки вони не встили стати трюїзмами»); зазначає у вступі, що не торкатиметься впливу на середню школу військових і революційних подій, а зосередиться лише на головній причині незадовільного стану школи, відчутній задовго до 1914 року. Йдеться про невідповідність старих програм новому контингенту учнів.

Він пояснює, що дореволюційні гімназії приймали учнів за конкурсом. Але сучасні приватні гімназії призвели до так званої демократизації школи, тобто, по-перше, до збільшення кількості учнів і, по-друге, до зниження їх якості. Незалежно від ставлення до першої чи другої частини поняття «демократизація школи», з цією реальністю доводиться рахуватися всім. I це зумовлює переоцінку попередньо утвердженого місця та ролі класики в навчальному процесі (Селивачёв, 1918a, с. 1-2).

Говорячи про фольклор, Олексій Федорович іронізує над спробами фольклористів зобразити великоруський епос у вигляді поетичного морального катехізису (О. Міллер, А. Сиротинін). Наводить і протилежні думки щодо брутальності та несмаку билин (В. Бєлінський, І. Тургенєв, І. Бунін). Солідаризуючись із ними, розгортає низку конкретних прикладів. Зокрема: зухвалість i, говорячи сучасною мовою, хуліганство та жорстокість Іллі Муромця (Селивачёв, 1918а, с. 11).

Так звані «нижчі епічні пісні», зібрані О. Соболевським у 1-му томі «Великоруських народних пісень» (Соболевский, 1895), виводять уже цілу низку жахливих типів, зухвалих вихваток і безмежного цинізму. Олексій Федорович підрахував, що з-поміж 479 варіантів пісень важко знайти таку, що не ображала б морального почуття. Приміром, їх улюблений герой - Ванька-ключник, який звабив дружину князя. Народ захоплений сміливістю Ваньки, його красою, молодістю, відвагою перед шибеницею. Проте в жодному варіанті сюжету (№ 25-48) нема й натяку на любов до княгині, що частково б виправдовувала Ваньку. Натомість останній цинічно підкреслює, що завдяки їй він солодко їв, добре пив і гарно вдягався.

Така зухвалість, - відзначає Олексій Федорович, не могла не вразити Ф. Сологуба (Сологуб, 1909), який зробив героями своєї повісті пісенного Ванькуключника та вигаданого ним пажа Жеана, протиставляючи великоруську підлість європейській галантності. Подібну ж огиду викликає оспівування спритного холопа (№ 51-59), котрий зачарував і панну, і її дочку, та ще й весело погрожує викрасти останню.

Якщо поблажливість народної маси до цих персонажів можна витлумачити ненавистю до панів (а чим вони уявляються у фольклорі, видно з № 274-278, де 
дівчина помирає від одного тільки страху перед залицяннями пана), то жодного виправдання нема для оспівування хоч би того «нежонатого» славного парубка (№ 247-250), котрий, сидячи під липою, співає під гуслі про своє «одруження», що загрожує в'язницею. Багато пісень оспівують страшні злочини без реальної мотивації.

Щоправда, не всі пісні схвалюють подібні злочини, скоєні з незрозумілих мотивів, але в автора (гадаємо, не без впливу тодішніх буремних подій) лишається гнітюче враження, що незчисленні звірства й жорстокості - чи не головна тема для оспівування вітчизняним фольклором. В інших випадках злочини вмотивовані, проте жодною мірою не виправдовують жорстокості.

Відтак Олексій Федорович вважає ознайомлення з такими піснями шкідливим, оскільки воно може в учнях із брутальними схильностями їх посилити, натомість у натурах естетичних і гуманних викликати відразу до народної творчості й самого народу, «що небажано, незалежно від питання, була б ця антипатія заслуженою, чи ні» (Селивачёв, 1918b, с. 16).

Переконуючи в незручності шкільного вивчення народної поезії в повному складі (необхідному при історико-літературному методі), він пропонує розглянути з тієї ж точки зору деякі твори класичного письменства, зокрема К. Батюшкова. Підручники та хрестоматії ніколи не викладають і не передруковують романтичних його творів у античному смаку, що мають найбільше поетичне значення. Отож учень, який вивчає Батюшкова за гімназичними посібниками, не розуміє, чому саме цей письменник заслуговує уваги.

У своєму дещо епатажному несприйнятті О. Пушкіна для цілісного вивчення гімназистами, молодий 30-літний педагог залучає в союзники цілий ряд авторитетів із різних ідеологічних напрямів. Зокрема, закоханого в геній О. Пушкіна М. Гоголя, котрий сам собі боявся в цьому зізнатися («Выбранные места», гл. XIV «Об односторонности») (Гоголь, 1898); Д. Писарєва, Л. Толстого, М. Неплюєва. Останній, син чернігівського губернатора, відомий спробами радикально реформувати суспільство на християнських засадах, у творі «Что есть истина», отд. II «Жизнь по обычаю мира сего» (Неплюев, 1901, с. 156-162) розглядає паралельно творчість О. Пушкіна й С. Надсона та доводить, що ці «два цілком протилежні за духовним настроєм поети обидва здатні справити гнітюче враження на всякого вразливого юнака, талановито застилаючи від очей сонце правди, зваблюючи один - на п'яний розгул, другий - на сумне життя» (Селивачёв, 1918а, с. 17).

3 дивовижним полемічним запалом Олексій Федорович повстає проти оспівування Пушкіним лінощів. Очевидно, педагогічна доцільність затьмарила йому в суворі роки громадянської війни просту істину, що риторично вихваляючи «лінощі», поет має на увазі передусім вільне від обов'язку напруженої праці дозвілля, години роздумів, молитви, медитації, коли геній може належати своїм незапланованим думкам.

І тоді стануть зрозумілішими епітети до «лени», яку поет іменує «золотою» («Всеволжскому»), «мудрою», «похвальною», своєю царицею та навіть єдиною богинею («Сон»), в якої він у полоні (ibidem), називаючи себе «молодым ленивцем» («Моему Аристарху»), «счастливой лени верным сыном» («К товарищам 
перед выпуском») і «повесой вечно праздным» («Послание Юрьеву»). Він живе «на лоне лени» («Чернильница»), «мнет луга своей бродящей ленью» («Домовому»), «с Вакхом нежится лениво» («Воспоминание»), знає «наслажденье ленью сонной» («К *** ») і зізнається: «Весь день, отъявленный ленивец, не зная дум других и дел, мечтаю я»; «лень, укрыв меня в пустынну сень, своею цепью чувства вяжет» («К Юдину»).

Справді захоплює терпляча наполегливість, із якою О. Селівачов вишукує з творів О. Пушкіна всі варіанти, скажімо так, «ледачої парадигми», ніби милуючись ефектами власної ретельності: «Приди, о лень, в мою обитель» («Сон»); «Меж лени и Морфея беспечный дух лелея, еще хоть год один позволь мне полениться» («Дельвигу»), заповідає йому ж «и лень, и лиру», а друзям - «память прошлых красных дней, окованных счастливой ленью» («Мое завещание»); сподівається випросити перед смертю «лишний миг у верной лени» («Кривцову»).

О. Пушкін закликає свого шкільного товариша А. Дельвіга: «Любовью, дружеством и ленью укрытый от забот и бед, живи под их надежной сенью»; називає викладача Галича «мудрецом ленивым» и каже йому: «тебя зовут и сон ленивый, и кубок, полный через край». Те, що більшість наведених цитат узято зі шкільних екзерсисів О. Пушкіна, не пом'якшує, на думку Селівачова, їхньої антипедагогічності, навпаки, дає привід учневі-ледарю виправдовуватися, що лінощі не завадили Пушкіну стати предметом вивчення в школі, на що викладачеві важко буде переконливо заперечити.

Напевно, жахи війни й революції зумовили несприйняття О. Селівачовим оспівування чи романтизації класиками мілітарної героїки (Но что прелестней и живей / войны, сражений и пожаров, / кровавых и пустых полей), хоча такого не бракує й у новій поезії, наприклад, у Р. Кіплінга чи М. Гумільова.

Показово, що в лекції про О. Пушкіна (збереглися прикінцеві сторінки 13-18 рукопису) (Селівачов, 1916b) головним у його творчості названо християнські мотиви всепрощення. Вони лунають у творах, де діють як позитивні літературні герої (літописець Пімен, Тетяна Ларіна, старий батько Земфіри), демонічні персонажі (Алеко, Євгеній Онєгін, Фауст) так і реальні постаті (Моцарт і Сальєрі), історичні діячі, представники влади, яких не можна вимірювати тією ж моральною мірою, що й звичайних людей. Серед них царі Борис Годунов, Василій Шуйський, Петро I, гетьман Мазепа, Наполеон Бонапарт, імператор Олександр I та ін. I ліричний герой Пушкіна схильний прощати тих, хто завдав йому лиха, причому не тільки в плані особистому, а й у народному.

Не менш обережний Олексій Федорович і в оцінці дидактичного потенціалу поезії М. Лермонтова, шкідливість якої «визнається навіть і тими, хто співчутливо ставиться до поезії О. Пушкіна, наприклад, В. Соловйовим. Заступаючись перед останнім за М. Лермонтова, Д. Мережковський (2002) все-таки зображає його настільки огидно, що апологія не досягає мети» (Селивачёв, 1918а, с. 22-23). Богоборство М. Лермонтова, на переконання О. Селівачова, зовсім не те, що в Іова Багатостражденного, або в Івана Карамазова. Лермонтов протестує не проти світового зла, котре він особисто примножує, а проти неможливості реалізувати свою безмежну гордість. Недарма ж улюблений твір Михайла Юрійовича, в якому він зобразив самого себе - «Демон». 
Але вчителі словесності зазвичай представляють поезію М. Лермонтова, порівнювану Селівачовим із розривною бомбою. Вони висувають на перший план найменш характерні його твори: «Ангел», «В минуту жизни трудную», «Я, Матерь Божия», «Когда волнуется». Попри це вчителі все-таки не можуть уникнути детального розгляду роману «Герой нашего времени». Знайомство з ним учнів, - завершує свій розгляд Олексій Федорович, - не дасть їм жодної користі, якщо постать головного героя Печоріна виявиться для них чужою та незрозумілою, та завдасть шкоди, коли він їх зацікавить і викличе симпатію. (Селівачов, 1918a, c. 23).

О. Селівачов доходить висновку, що при подібному вибірковому підході неможливо сфрормувати наукове, всебічне, цілісне сприйняття розвитку художньої літератури саме як історичного процесу, тому правильніше буде відмовитися від претензій на викладання «історії» й обмежитися вивченням окремих найбільш показових творів.

Свою позицію він підкріплює схожими міркуваннями, висловленими в підручнику «Родной язык в средней школе» (Алферов, 1911). Замінювати ж для характеристики епохи живі образи конкретних персонажів із літературних творів абстрагованими, зовсім не варто. На думку Селівачова, ненауковість такого засобу, використовуваного задля легкості багатьма письменниками, котрі вважають себе істориками культури (наприклад, Д. Овсянико-Куликовський та інші), переконливо з'ясована М. Гершензоном (Лансон, 1911) у післямові до його перекладу «Методу в історії літератури» Густава Лансона.

\section{- Висновки}

3'ясовано, що розглянуті тексти О. Селівачова яскраво відбивають ідейні суперечності революційної доби щодо ставлення до класики та новітніх форм художньої творчості в аспекті пріоритету естетичних або морально-дидактичних критеріїв.

Ентузіастично підтримуючи (попри власну швидше консервативну світоглядну позицію) ще не визнане всіма сучасниками мистецтво модерністів, О. Селівачов усвідомлює відсутність прямої відповідності між естетикохудожніми преференціями, політичними та релігійними переконаннями, й це підтвердили наступні події. Він знає, що конфрлікти старого й нового неминуче тривають упродовж усієї історії, набуваючи своєрідних особливостей у кожному епосі та країні. Проте в ранніх апологетичних статтях 1911-1916 років ніби виправдовує модерністів (К. Бальмонта, О. Блока, В. Брюсова, В. Іванова, Ф. Сологуба, М. Чурльоніса) за ті самі «антипедагогічні» мотиви (зокрема, егоїстичні, демонічні), що 1918 року так дошкулятимуть йому в народній творчості та у класиків, передусім у О. Пушкіна й М. Лермонтова.

Розкрито своєрідну зміну віх у текстах О. Селівачова після 1917 року. 3'ясовано, що зумовлено це не політичною кон'юнктурою, адже в тогочасному Харкові 1918-1919 рр. влада найдовше належала не більшовикам, а німцям, гетьманцям, денікінцям. Швидше йдеться про загальне усвідомлення кінця культури імперського періоду. Імена уявних ідейних союзників, які залучає О. Селівачов, показують широке коло критиків і класики, й фольклорної традиції, котрі пред- 
ставляють усі напрями культурно-соціологічної думки XIX століття. Тут і революціонери-демократи (В. Бєлінський, М. Добролюбов, Д. Писарєв), і ліберали (І. Бунін, М. Гершензон, І. Тургенєв), і консерватори містичних і слов'янофрільських відтінків (М. Гоголь, О. Міллер, С. Соловйов, А. Соболевський), і шукачі релігійного відродження (Д. Мережковський, М. Неплюєв, Л. Толстой). При цьому вплив багатьох із них відчувається в текстах молодого харківського вченого.

Продемонстровано помітне прагнення О. Селівачова зрозуміти та пояснити протиріччя в творах і вчинках досліджуваних ним персонажів, оскільки суперечності, як чинники поступу, постійно привертали увагу науковця, наприклад, у його найбільших за обсягом основних працях про таких парадоксальних мислителів, як Георг Даумер, Василій Розанов, Фріц Маутнер.

Зрештою, тексти О. Селівачова переконливо відображують, якими саме шляхами глорифікація наприкінці XIX ст. фольклорної та поетичної класики швидко змінювалася на початку наступного століття критичним ставленням. I сприяли цьому найрізноманітніші чинники у широкому спектрі від консервативних антипрогресистських ідей - до модерністських і авангардних інтенцій радикального оновлення.

\section{- Список використаних джерел}

Алферов, А. Д. (1911). Родной язык в средней школе (Опыт методики) Сотр. школа. Гаврилюк, А. (2020). Роль родинної традиції у становленні творчої особистості (на прикладі п'яти поколінь Селівачових). Народознавчі зошити, 1, 177-189.

Гоголь, Н. (1898). Сочинения (Т. 5, 14-е изд.). Издание А. Ф. Маркса.

Лансон, Г. (1911). Метод в истории литературы (М. Гершензон, Пер.). Товарищество «Мир».

Мережковский, Д. (2002). М. Ю. Лермонтов-поэт сверхчеловечества. В В. М. Маркович, \& Г. Е. Потапова (Сост.), М. Ю. Лермонтов: pro et contra Русский христианский гуманитарный институт.

Неплюев, Н. Н. (1901). Собрание сочинений (Т. 1) Типографрия и Литография В. А. Тиханова Пучков, А. (2003). Олексій Селівачов. АНТ: Вісник археології, мистецтва, культурної антропології, 10-12, 119-120.

Пучков, А., \& Марченко, Ю. (2016). Алексей Фёдорович Селивачёв, виленский учитель Бахтина. К становлению отечественной культурологии. В М. С. Уколова, А. В. Никитина, \& А. Ю. Николаева (Ред.). Никоновские чтения (Т. 1: Актуальные вопросы культурологии и искусствоведения, с. 259-264). Чувашский государственный педагогический университет.

Селивачёв, А. (1911). Из современной русской лирики [Рукопись]. Лейпциг.

Селивачёв, А. (1915). Вячеслав Иванов как мистик [Рукопись]. Вильно.

Селивачёв, А. (1916а). Георг Фридрих Даумер. История одной души. Вопросы философии и психологии, 135, 329-355.

Селивачёв, А. (1916b). Лекция о Пушкине [Рукопись]. Харьков.

Селивачёв, А. (1916с). О методах ведения сочинений [Рукопись]. Харьков.

Селивачёв, А. (1917). Психология юдофильства. Русская мысль, 2, 40-64.

Селивачёв, А. (1918а). О преподавании русского языка и словесности в средней школе [Рукопись]. Харьков. 
Селивачёв, А. (1918b). Сологуб. [Рукопись]. Харьков.

Соболевский, А. (1895). Великорусские народные песни (Т. 1). Государственная типографияя.

Сологуб, Ф. (1909). Ванька ключник и паж Жеан: Драма в 12 двойных сценах (Музыка В. А. Сенилова). Журнал «Театр и искусство».

Puczkow, A., \& Marczenko, Ju. (2013). Alexy Seliwaczew - wileński nauczyciel Michała Bachtina. Znad Wilii, 4(56), 104-110.

\section{References}

Alferov, A. D. (1911). Rodnoi yazyk $v$ srednei shkole (Opyt metodiki) [Native language in secondary school (Methodology experience)]. Sotr. shkola [in Russian].

Gogol', N. (1898). Sochineniya [Work] (Vol. 5, 14-th ed.). Izdanie A. F. Marksa [in Russian].

Havryliuk, A. (2020). Rol rodynnoi tradytsii u stanovlenni tvorchoi osobystosti (na prykladi p'iaty pokolin Selivachovykh) [The role of family tradition in the formation of creative personality (on the example of five generations of Selivachevs)]. The Ethnology Notebooks, 1, 177-189 [in Ukrainian].

Lanson, G. (1911). Metod v istorii literatury [Method in the history of literature] (M. Gershenzon, Trans.). Tovarishchestvo «Mir» [in Russian].

Merezhkovskii, D. (2002). M. Yu. Lermontov - poet sverkhchelovechestva [M. Yu. Lermontovpoet of supermanity]. In V. M. Markovich, \& G. E. Potapova (Comp.), M. Yu. Lermontov: pro et contra. Russkii khristianskii gumanitarnyi institut [in Russian].

Neplyuev, N. N. (1901). Sobranie cochinenii [Collected Works] (Vol. 1) Tipografiya i Litografiya V. A. Tikhanova [in Russian].

Puchkov, A. (2003). Oleksii Selivachov [Alexey Selivachev]. ANT: Visnyk arkheolohii, mystetstva, kulturnoi antropolohii, 10-12, 119-120 [in Ukrainian].

Puchkov, A., \& Marchenko, Yu. (2016). Aleksei Fedorovich Selivachev, vilenskii uchitel' Bakhtina. K stanovleniyu otechestvennoi kul'turologii [Alexey Fedorovich Selivachev, Bakhtin's Vilna teacher. Towards the formation of Russian cultural studies]. In M. S. Ukolova, A. V. Nikitina, \& A. Yu. Nikolaeva (Eds.), Nikonovskie chteniya [Nikon Readings] (Vol. 1: Aktual'nye voprosy kul'turologii i iskusstvovedeniya [Topical Issues of Cultural Studies and Art Criticism]), pp. 259-264). Chuvashskii gosudarstvennyi pedagogicheskii universitet [in Russian].

Puczkow, A., \& Marczenko, Ju. (2013). Alexy Seliwaczew - wileński nauczyciel Michała Bachtina [Alexy Selivachev - Mikhail Bakhtin's teacher from Vilnius]. Znad Wilii, 4(56), 104-110 [in Polish].

Selivachev, A. (1911). Iz sovremennoi russkoi liriki [From modern Russian lyrics] [Manuscript]. Leiptsig [in Russian].

Selivachev, A. (1915). Vyacheslav Ivanov kak mistik [Vyacheslav Ivanov as a mystic] [Manuscript]. Vil'no [in Russian].

Selivachev, A. (1916a). Georg Fridrikh Daumer. Istoriya odnoi dushi [Georg Friedrich Daumer. The story of one soul]. Voprosy filosofii i psikhologii, 135, 329-355 [in Russian].

Selivachev, A. (1916b). Lektsiya o Pushkine [Lecture on Pushkin] [Manuscript]. Khar'kov [in Russian].

Selivachev, A. (1916c). O metodakh vedeniya sochinenii [On the methods of writing essays] [Manuscript]. Khar'kov [in Russian]. 
Selivachev, A. (1917). Psikhologiya yudofil'stva [Psychology of Judophilia]. Russkaya mysl', 2, 40-64 [in Russian].

Selivachev, A. (1918a). O prepodavanii russkogo yazyka i slovesnosti v srednei shkole [Teaching Russian language and literature in secondary school] [Manuscript]. Khar'kov [in Russian].

Selivachev, A. (1918b). Sologub. [Manuscript]. Khar'kov [in Russian].

Sobolevskii, A. (1895). Velikorusskie narodnye pesni [Great Russian folk songs] (Vol. 1). Gosudarstvennaya tipografiya [in Russian].

Sologub, F. (1909). Van'ka klyuchnik i pazh Zhean [Vanka the key keeper and the page Zhean]: Drama in 12 double scenes (Muzyka V. A. Senilova). Zhurnal «Teatr i iskusstvo» [in Russian].

\title{
PERCEPTION AND TEACHING ISSUES IN ARTISTRY THROUGH THE TEXTS OF ALEXEY SELIVACHYOV, KHARKIV CULTURAL STUDIES SCHOLAR
}

\author{
- Havryliuk Alla \\ - PhD student, \\ ORCID: 0000-0002-6833-6462, e-mail: alla_stepp@ukr.net, \\ Kyiv National University of Culture and Arts, \\ Kyiv, Ukraine
}

\section{- Abstract}

The purpose of the article is to specify the ideological, aesthetic and ethical factors of a drastic reassessment of the value of the classics for the modernity of the beginning of the $20^{\text {th }}$ century, in the period that is commonly called the Silver Age of culture. The processes of such reconsideration, where the culminating point was the vulgar sociological humiliation of the artistic classics as a result of the events of 1917, began not in the proletarian environment, but in academic circles, which subsequently suffered the most from the revolution. The relevance of the topic stems from the coverage of one of the aspects of the change in the humanitarian discourse at the stage of the revolutionary transition from one sociopolitical formation to another - exactly a century ago. The objective outlined in the purpose of the article is studied on the basis of the analysis of the scientific and journalistic activities of one of the talented young representatives of the academic Kharkiv environment, who wrote a dissertation under the guidance of Academician M. Sumtsov and considered the issues of perception and teaching of artistic creativity. The sources of the study were mainly unpublished manuscripts of A. Selivachyov, which are preserved in the family archive. The scientific novelty of the article lies in the introduction of these sources into scientific circulation. Conclusions. It has been demonstrated that the glorification of the folklore and poetic classics at the end of the $19^{\text {th }}$ century was quickly replaced by a critical attitude at the beginning of the next century. And this was facilitated by a wide variety of factors, from conservative antiprogressive ideas to modernist and avant-garde intentions of radical renewal.

Keywords: artistic creativity; poetry; perception of a work of art; reassessment of values; classics and modernity; teaching; the Silver Age 


\title{
ВОСПРИЯТИЕ И ПРЕПОДАВАНИЕ ХУДОЖЕСТВЕННОГО ТВОРЧЕСТВА ПО ТЕКСТАМ ХАРЬКОВСКОГО КУЛЬТУРОЛОГА АЛЕКСЕЯ СЕЛИВАЧЁВА
}

\author{
- Гаврилюк Алла Степановна \\ - Аспирантка, \\ ORCID: 0000-0002-6833-6462, e-mail: alla_stepp@ukr.net, \\ Киевский национальный университет культуры и искусств, \\ Киев, Украина
}

\section{Аннотация}

Цель статьи - конкретизировать мировоззренческие, эстетические и этические факторы радикальной переоценки значения классики для современности в начале XX века, в период, который принято называть «серебряным веком» культуры. Актуальность темы следует из освещения одного из аспектов изменения гуманитарного дискурса на этапе революционного перехода от одной социально-политической формации к другой. Методология исследования. Обозначенная целью статьи проблема рассматривается на основе анализа научно-публицистической деятельности одного из талантливых молодых представителей академической харьковской среды, который писал диссертацию под опекой академика Н. Сумцова, исследуя проблемы восприятия и преподавания художественного творчества. Источниками исследования послужили в основном неопубликованные рукописи А. Селивачёва, хранящихся в семейном архиве. Научная новизна заключается во введении в научный оборот означенных источников. Выводы. Процессы такого переосмысления, где высшей точкой стало вульгарно-социологическое уничижение художественной классики вследствие событий 1917 года, начались не в пролетарской среде, а в академических кругах, которые впоследствии больше всего пострадали от революции. Продемонстрировано заметное стремление А. Селивачёва понять и объяснить противоречия в произведениях и поступках исследуемых им персонажей, поскольку противоречия, как фракторы развития, постоянно привлекали внимание ученого. Выявлено, что рассмотренные тексты А. Селивачёва ярко отражают идейные противоречия революционной эпохи по отношению к классике и новых форм художественного творчества в аспекте приоритета эстетических или морально-дидактических критериев. Выяснено, что восславление в конце XIX века фольклорной и поэтической классики быстро сменялось в начале следующего столетия критическим отношением. Способствовали этому самые разнообразные фракторы в широком спектре от консервативных антипрогрессистских идей - к модернистским и авангардным интенциям радикального обновления.

Ключевые слова: художественное творчество; поэзия; восприятие художественного произведения; переоценка ценностей; классика и современность; преподавание; серебряный век 